https://doi.org/10.18485/iipe_60nam.2021.ch9

\title{
RELATIONS OF THE NON-ALIGNED MOVEMENT WITH OTHER REGIONAL MOVEMENTS AND ORGANISATIONS DURING THE COLD WAR
}

\author{
Lorenz M. LÜTHI ${ }^{1}$
}

\begin{abstract}
Despite overlapping agendas, the Non-Aligned Movement entertained awkward relations with the major regional movements and organisations outside of Europe and North America during the Cold War. The movement consisted of an ever-growing number of Asian, Arab, African, and Central and South American members that shared an increasingly disparate list of interests and goals. Hence, the Non-Aligned Movement itself often lacked a clear direction in its own policies and also in its relations with other regional movements and organisations. Conversely, these movements and organisations also pursued goals that sometimes were diametrically opposed or, at least, hardly incompatible with the Non-Aligned Movement. Organisations in South East Asia and the Americas were mostly Cold War creations that clashed with the fundamental block-free outlook of Non-Alignment. In other cases, the internal Cold War conflicts within the Bandung Movement and the Arab League carried over into the Non-Aligned Movement. And the Organisation of African Unity did not seek closer collaboration, despite friendly relations and similarity of interests, largely because it directed its diplomatic efforts towards another international organisation - the United Nations. Ultimately, during the Cold War, the Non-Aligned Movement faced an uphill struggle in collaborating with like-minded organisations.
\end{abstract}

Key words: Non-alignment, Bandung, ASEAN, SEATO Arab League, Organisation of African Unity, Organisation of American States.

\footnotetext{
${ }^{1}$ Associate Professor, McGill University, Montreal, Canada.

E-mail: lorenz.luthi@mcgill.ca
} 


\section{The NAM from its Foundation in 1961 to its Decline in the 1980s}

The Non-Aligned Movement (NAM) emerged in 1961 among neutralist nations that sought greater influence in global affairs through a collective voice. The basic condition for membership was block-free status in the world, i.e., non-membership in any of the Cold War alliances. Yet, the member states did not agree rigidly on one single definition of nonalignment. Some like India refused military aid from either superpower, at least until 1962; others like Saudi Arabia or Vietnam were in quasi-military alliance with the United States or the Soviet Union, respectively (Lüthi, 2020, pp. 288-91). The NAM was one of many movements of states in the $20^{\text {th }}$ century that worked for world peace on the basis of similar agendas and shared interests - i.e., anti-imperialism, block-free status, and economic development. Since these movements often had overlapping memberships, observers have occasionally confused them. For instance, historians and even participants merged the Non-Aligned Movement with the Bandung Movement (Asian-African Internationalism), although the two were distinct and even ended up as bitter rivals in the early 1960s (Jansen, 1966; Dinkel, 2015). The Non-Aligned Movement was not a regional movement, even if many of its members were from the decolonised Global South, particularly from Asia, the Arab world, and sub-Saharan Africa. Despite a number of neutral states in Europe during the Cold War, only one European state was Non-Aligned-founding member Yugoslavia. As a result, the movement pushed for goals that often represented the poorer majority of the world's state system. Nevertheless, the Non-Aligned Movement entertained thorny, and in some cases even competitive, relations with many of the regional movements and organisations that emerged in the world outside of Europe and North America. This was related, on the one hand, to the diversity and increasing internal paralysis of the NAM in the 1970s, but also, on the other hand, to the Cold War nature of some of these regional organisations. Intellectually, India's first Prime Minister, Jawaharlal Nehru, was the first to define non-alignment in the late 1940s. From late 1954 to mid-1956, Yugoslavia's Josip Broz Tito and Egypt's Gamal Abdel Nasser agreed with Nehru's ideas of neutralism in the Cold War, although both leaders had sought alternatives to superpower-led block formation for some years before. Against Nehru's strident opposition, Tito and Nasser then pushed for the formal launch of the NAM. By 1961, they succeeded with the convocation of the first Non-Aligned Conference in Belgrade, followed by another one in 1964 in Cairo (Lüthi, 2016, pp. 203-10). The movement attracted much international attention, particularly in terms of nuclear arms 
limitation in the early 1960s. Yet, its lack of institutionalisation, its increasing and diverse membership, and its generally amorphous political agenda meant that it achieved its influence mostly on the basis of charismatic leadership by some of its founding fathers. Nehru's death in 1964 and Nasser's passing in 1970 drove home the necessity to think harder about institutionalisation (Lüthi, 2020, pp. 302-6). The Non-Aligned Movement entered troubled waters as early as 1964 . On the basis of its successful nuclear test in October 1964, Communist China tried to seize political leadership of the rival Bandung Movement. Even if it destroyed that movement within one year by its own radicalism, its poisonous discourse undermined the internal unity of the NAM as well, largely because a significant number of states were members in both. The June War in the Middle East in 1967 further paralysed the movement, as did Tito's subsequent attempts to seek closer collaboration with the Socialist World, which floundered with the Soviet-led intervention in Czechoslovakia in August 1968 (Lüthi, 2020, pp. 297-300). Non-Alignment entered the following decade shaken by the $2^{\text {nd }}$ Vietnam War (1964-75) and the Jordanian crisis in September 1970. In their wake, the movement introduced both greater institutionalisation and regular three-year schedules of recurrent meetings that would end with a summit in changing host countries. Nevertheless, the growth of member states made consensus finding more and more difficult. As the movement was increasingly leaning towards the Socialist World over the course of the 1970s, Communist states like Vietnam and North Korea, which were quasi-allied with the Soviet Union, entered and then tried to seize leadership in cooperation with other radical members, like Cuba. Founding members, who were committed to the original ideas of non-alignment, found it increasingly difficult to contain the emerging leftist radicalism, which often assumed an anti-American penchant. The peak of this development occurred at the Havana Summit in 1979, which Cuba had prepared in cooperation with the Soviet Union. Disappointed by these developments, founding member Burma left the movement (Lüthi, 2020, pp. 302-6, 531-33). Hence, at the turn of the decade, the Non-Aligned Movement started to fall on hard times. With the Vietnamese intervention in Cambodia in late 1978, two Non-Aligned members went to war for the first time. A year later, the Soviet Union intervened in Non-Aligned founding member Afghanistan. And in the fall of 1980, with the Iraqi attack on Islamic Iran, another two member states went to war against each other. Paralysed by its pre-existing internal conflicts, the NAM failed to find a common voice in condemning all three conflicts. To make matters worse, Iraq had been chosen to host the 1982 
Summit while it continued its war with Iran. Under Indian pressure, the summit was postponed and then moved to Delhi in 1983. Poignantly, India, thereby assumed leadership of a movement, the creation of which it had fought only a quarter of a century before. Yet, the internal conflicts of the previous ten years had lastingly damaged the moral reputation of the NonAligned Movement. Its annual meetings and triennial summits no longer attracted the high-ranked representatives of member states as it had in the 1960s; the charismatic founding fathers Tito, Nasser and Nehru all had died between 1964 and 1980. The movement was led by leaders of lesser stature and lesser international influence. And with the end of the Cold War by the late 1980s, the main reason for its very existence-block-free status vanished. The NAM has survived until today, but it is merely a faint shadow of its former standing in the world (Lüthi, 2020, pp. 533-35). Non-alignment drew both strength and competition from a variety of regional movements and organisations. Asian-African Internationalism (the Bandung Movement), which, mostly based on Asian and Arab participation, had a major intellectual and political impact on early Non-Alignment became a major competitor by the early 1960s. The South East Asian Treaty Organisation (SEATO) and the Association of South East Asian Nations (ASEAN) were mostly anti-Communist rivals to the NAM, which triggered mutual conflict throughout the whole period. As the Cold War split the Arab League, neutral members, with Nasser's Egypt in the lead, were crucial in establishing the Non-Aligned Movement, but thereby ensuring a difficult relationship between the two. In Africa and the Americas, personal rivalries and ideological clashes prevented closer collaboration of Non-Alignment with the Organisation of African Unity (OAU) and the Organisation of American States (OAS).

\section{Asian-African Internationalism}

Asian-African Internationalism (a.k.a. Afro-Asianism, or the Bandung Movement) preceded the Non-Aligned Movement, although both have Indian roots and hence are often conflated. As future Prime Minister, Jawaharlal Nehru prepared India for independence in the late 1930s and throughout much of the 1940s, he pondered how his independent country should position itself in global affairs. At independence, he had endorsed non-alignment as a positive force for peace. Non-Aligned India would actively engage in international affairs but neither belongs to a military block nor relies heavily on military aid from another major power. India's nonalignment was based on engagement with but equidistance to the 
superpowers (Lüthi, 2016, pp. 203-10). This was also the position which Nehru hoped the Asian-African Movement would adopt at its famous conference in Indonesia's Bandung in April 1955. Nehru had been sceptical since 1953 about Indonesia's plans to call for such a conference. However, once the United States had established the Southeast Asian Treaty Organisation (SEATO) in September 1954 in the wake of the Korean War (1950-53) and the Geneva Conference on Korea and Vietnam (April to July 1954), he not only changed his mind but also decided to take the lead in shaping the Bandung Conference (Lüthi, 2020, pp. 275-78). However, the Afro-Asian Movement was not based on common political goals but on a shared geography. Most of its 29 members were Asian and Arab states, with only three African states (Ethiopia, Liberia, and Gold Coast/Ghana) attending. While two participants (China and North Vietnam) were communist, five were outright US allies (Turkey, Iraq, Pakistan, Thailand, and the Philippines) and some more clearly pro-Western (Libya, Jordan, Iran and South Vietnam). In this context, Nehru faced strong opposition to his rigid definition of non-alignment. Despite many compromises made in the preparations beforehand and during the conference to ensure the gathering would be a success, Nehru left Bandung disillusioned about the power of international conferences and movements. Given the flickering internal disagreements within the Global South, Nehru subsequently rejected calls for another Asian-African conference or for the creation of a Non-Aligned alternative, which Egypt's Nasser and Yugoslavia's Tito hope to launch (Lüthi, 2020, pp. 278-83). Despite their Nehruvian roots, the sibling Bandung and Non-Aligned Movements emerged as strident rivals in the first half of the 1960s. As Communist China radicalized its domestic and foreign policies, particularly after 1962, and Indonesia assumed pro-Chinese and anti-Indian positions, their repeated calls for convening a new Bandung Conference around the tenth anniversary of the first one clashed with the non-aligned preferences of Ceylon (Sri Lanka), Egypt, and Yugoslavia. The People's Republic of China (and the Soviet Union) had already tried to subvert the Afro-Asian People's Solidarity Organisation, which emerged as an Egyptian-led off-shot of the Bandung Movement in 1957. The conflict between Asian-African Internationalism and the NAM came to the fore in late 1962 when Afro-Asian Non-Aligned members tried to mediate in the Sino-Indian conflict in the Himalayas. The rigid Chinese position and Indian fears of Chinese attempts to undermine its standing in the Afro-Asian world greatly deepened the antagonism between the two sibling movements (Čavoški 2017). In early 1963, Nehru himself decided to give up on AsianAfrican Internationalism and instead endorse the Non-Aligned Movement 
wholeheartedly. Subsequently, Ceylon, Egypt, and Yugoslavia won the race for the $2^{\text {nd }}$ conference against China and Indonesia convening a gathering in Egypt in early October 1964. China's attempt to exploit its nuclear test shortly thereafter to seize the Bandung Movement failed by mid-1965 when the scheduled $2^{\text {nd }}$ Afro-Asian conference in Algiers was first delayed after Ben Bella's overthrow and then eventually cancelled. Yet, Communist China's anti-American, anti-Soviet, and anti-Indian rhetoric in 1963-65 not only destroyed the Bandung Movement but also deeply damaged cohesion in the Global South, at large, and within the Non-Aligned Movement, in particular (Lüthi, 2020, pp. 283-85, 297-300).

\section{Southeast Asia}

Non-Aligned relations with the SEATO (1954-79) and its de facto successor ASEAN (since 1967) were greatly affected by the Cold War. Nehru had failed in imposing his non-aligned visions on the Bandung Movement in 1955 in the wake of the creation of the SEATO. Yet, a less rigid version of his ideas - block-free status - came to fruition with the Yugoslav-Egyptian foundation of the Non-Aligned Movement in September 1961. Unlike India, Yugoslavia and Egypt both had entertained close military supply relations with one of the superpowers for years. Nehru's strict rejection of such relations eventually faltered in the wake of the Sino-Indian border war in October 1962. Be it as it may, even the less rigid definition of non-alignment helped to improve the NAM's relations with the SEATO (Lüthi, 2020, pp. 289-90, 307). India was deeply troubled that its regional arch enemy and neighbour Pakistan was allied with the United States via the SEATO and its Middle Eastern pendant CENTO (Central Treaty Organisation), while Egypt equally disliked American-led Cold War alliance making in the Middle East (for both, see also the section on the Arab World below). As the SEATO's central purpose was to deter Communist aggression against the nonmember states Laos, Cambodia, and South Vietnam, the alliance was automatically drawn into the $2^{\text {nd }}$ Vietnam War after 1964 . Four SEATO members - the United States, Australia, Thailand, and the Philippines - sent troops to Vietnam, and some of the other SEATO members provided political and logistical support. Yet, ultimately, the SEATO turned out to be more wobbly scaffolding than sturdy concrete during the Vietnam War (Eckel, 1971). Faced with the Communist threat emanating from Indochina to the north, Indonesia, Malaysia, the Philippines, Singapore, and Thailand decided to establish the ASEAN in 1967. The new organisation was not a Cold War military alliance, but its political agenda (economic growth, social 
progress, cultural development, promotion of regional peace, collaboration and mutual assistance, and mutual assistance) still had a very strong antiCommunist bend. The regional organisation eventually found a greater sense of political purpose a dozen years after its foundation, in the wake of Vietnam's intervention in Cambodia in late 1978 (Jones \& Smith, 2007, pp. 150-51). However, since both the SEATO and the ASEAN were strongly anti-Communist during the Cold War, their overlapping goals were evidently antagonistic to Non-Aligned visions. As Non-Aligned founding member Cambodia was drawn into the $2^{\text {nd }}$ Vietnam War against its own will, the NAM needed to show colours with regard to that conflict. India had given up its neutralist position in Indochina by 1965 and eventually would recognise North Vietnam in early 1972. In August that year, the Foreign Ministers conference in Guyana faced requests to decide on the membership of Cambodia, which had become pro-American in a coup in March 1970, and membership of the Provisional Revolutionary Government (PRG; North Vietnam's puppet government in South Vietnam). The decision to award membership to both the Cambodia's exile government in Beijing and the PRG alienated the ASEAN-affiliated Non-Aligned members so much that the Guyana conference ended in a diplomatic éclat. The NonAligned decision in 1975 to award membership to recently unified, communist Vietnam and to North Korea (but not South Korea) did not help to bridge differences between the Non-Aligned Movement at large and its ASEAN-affiliated members (Lüthi, 2020, pp. 302-6). The rupture deepened when the NAM failed to condemn Vietnam's intervention in Cambodia in 1978 and the Soviet intervention in Non-Aligned Afghanistan a year later (Lüthi, 2020, pp. 531-35). By 1979, the ASEAN had forged a strong identity and cohesion among its own members that had developed clearly outside of the Non-Aligned Movement (NAUK, FCO 58/1574).

\section{The Arab World}

Despite overlapping memberships, relations between the Non-Aligned Movement and the Arab League were fraught with political disagreements and partially mutually exclusive goals. Since its foundation in 1945, the Arab League had experienced major internal conflicts along ideological lines that foreshadowed the Cold War. Some of its members - like Iraq, Jordan, and Saudi Arabia-were strongly anti-Communist, while others were neutralist-like the royal and then Nasserite Egypt - even if they initially were pro-Western. Yet, as the American alliance building in the wake of the outbreak of the Korean War in June 1950 extended the Cold War from 
Europe and East Asia to the entire periphery of the Socialist World, the superpower conflict had a major impact on the Arab League. With the Iraqi signature of the Baghdad Pact (CENTO since 1959) in February 1955, the league threatened to split into a pro-Western and a neutralist wing. Until early 1957, Saudi Arabia sided with Nasserite Egypt but eventually joined never formally, though - the pro-Western members. Poignantly, Iraq exited from the Baghdad Pact in 1959, in the wake of its leftist coup against the monarchy the year before. Still, despite changing associations with the one or the other wing, the Arab League remained internally split until the early 1970s (Lüthi, 2020, pp. 26-33, 52-66). It is in this context that neutralist Nasserite Egypt, together with Tito's Yugoslavia, strove to establish the Non-Aligned Movement. Ultimately, the NAM was strongly affiliated with the neutralist wing within the Arab League, even if pro-Western Saudi Arabia was also a Non-Aligned founding member. This asymmetric entanglement between the Arab League and Non-Alignment turned into a major problem during and after the June War in the Middle East in 1967. While all Arab states lined up behind non-aligned Egypt in the struggle against Israeli aggression, the Non-Aligned Movement was paralysed. Nasser's decision to lean heavily towards the Soviet Union during and after the war meant that the NAM suffered a major obstacle to keep and even enhance its influence in Middle Eastern and global affairs. Tito's decision to work closely with the Soviet Union in the 14 months after the war and his nascent attempts to form a quasi-alliance between Non-Alignment and the Socialist World further undermined the movement. The Soviet-led intervention in Czechoslovakia cured his pro-Soviet leanings, but the damage to the Non-Aligned Movement was difficult to undo (Lüthi, 2020, pp. 300-2). Many members criticised Tito's policies at the Belgrade consultative meeting in mid-1969, even if the Yugoslav leader had called the gathering to re-emphasise the NAM's basic non-alignment positions (NAUK, FCO 28/868). Conflict in the Arab world once more intruded on the $3^{\text {rd }}$ Summit in Lusaka in September 1970, which most Arab leaders did not attend on short notice due to the ongoing civil war in Jordan between the monarchy and Palestinian groups (PAAA-MfAA, C 522/72). While Nasser had pushed for the establishment of the NAM out of frustration of the Cold War division of the Arab League, his successor Anwar Sadat exploited in 1973 a re-unified Arab League and the NAM for political mobilisation in view of the October War against Israel. In the wake of Nasser's death in September 1970, Sadat had tried to switch sides in the Cold War. Yet, after he expelled Soviet military advisers in mid-1972, the United States did not respond to Sadat's desire to use US help to resolve the Arab- 
Israeli conflict. Frustrated, in October 1972, he decided on war against Israel. Unlike Nasser in 1956 and 1967, he sought - on the basis of Saudi political and diplomatic support-unity within the Arab League for renewed military conflict. Moreover, Sadat also realised the central importance of political backing from the world at large. This is why he and Saudi King Faisal used the 1973 Non-Aligned Summit in Algiers to convince African states to cut relations with Israel. As a result, Sadat went to war against Israel, which languished isolated except in the Western world, with unified Arab League and Non-Aligned support (Lüthi, 2020, pp. 230-38, 304). The concomitant Arab oil boycott targeted Western nations supporting Israel, while Saudi Arabia supported financially African Non-Aligned members that faced high world market oil prices as a result of the Arab boycott (PAAA-MfAA, C 486/77). Yet, the Egyptian-formed unity of purpose between the Arab League and Non-Alignment did not last. Frustrated by the American reluctance to address the basic problems in the Arab-Israeli conflict, Sadat's Egypt reached out unilaterally to Israel in 1977 to seek a peace deal. Afraid of being shut out, the United States finally engaged by helping the conclusion of a bilateral peace treaty in March 1979 (Lüthi, 2020, pp. 496-502). The Arab League, including Saudi Arabia, retaliated swiftly by excluding Egypt from its ranks (NAUK, PREM 16/2170). Furthermore, the league demanded a similar step from the NAM, which the Non-Aligned Summit in Havana in September 1979 rejected (NAUK, FCO 28/3923). Eventually, the Non-Aligned Movement faced one of its major Middle Eastern crises in September of 1980 when its member Iraq, supported by much of the Arab League, went to war against another Non-Aligned member, the Islamic Republic of Iran (Lüthi, 2020, pp. 534-35).

\section{Sub-Saharan Africa}

As Sub-Saharan Africa underwent decolonisation in the late 1950s and early 1960s, it was more likely to join the Non-Aligned than the Bandung Movement. Although Asian-African Internationalism was explicitly committed to anti-imperialism, the attempts by radicalized China to seize the Bandung Movement in the first half of the 1960s alienated many recently decolonised states in Sub-Saharan Africa. Thus, unlike the Bandung Movement, the NAM counted a large number of African members virtually since its foundation (Mathews, 1987, p. 44). Yet, relations between the NonAligned Movement and Pan-Africanism were difficult. In his attempt to increase Egypt's international standing after the Bandung Conference, Egypt's Nasser tried to mobilise sub-Saharan Africa (Matthies, 1977, p. 189). 
He also agreed to Tito's proposal to launch the NAM in early 1961 when the Yugoslav leader visited Cairo at the end of a long trip through Africa (AJ, KPR I-4-a/1). Hence, Nasser and Tito launched the new project with their eyes clearly fixed on a continent that was in the process of achieving independence from European colonialism. However, both faced African resistance to their plans of incorporating the continent's newly independent nations into Non-Alignment. Ghana's independence leader, Kwame Nkrumah, sought post-colonial African unity primarily on the basis of PanAfricanism. Nasser tried to rival Nkrumah's All-African People's Congress in Accra in December 1958 by staging a rivalling Afro-Asian Economic Conference (Lüthi, 2020, pp. 283). As a result of this rivalry, Nkrumah's Ghana was more interested in good relations with Egypt's arch enemy Israel than with Nasser's Egypt itself (Levy, 2003). While Nkrumah turned out to be an important voice in the foundation of the Non-Aligned Movement in 1961, he was one of the major promoters of the creation of the Organisation of African Unity, established in Addis Ababa in Non-Aligned founding member Ethiopia (Legum, 1975, p. 208). Although the OAU adopted the idea of non-alignment in its charter in 1963, and Egypt and other Arab states in North Africa joined the new organisation, the rivalry between Nkrumah and Nasser continued until the Ghanaian leader was overthrown in a coup in early 1966. Despite its generally friendly relations with the NAM and the engagement of individual African states like Mali and Zambia in the NAM, the OAU focused more on working closely with the Group of 77 (G-77) at the United Nations, in which many members were Non-Aligned (Matthies, 1977, pp. 190-91; Mathews, 1987, p. 47-48).

\section{Central and South America}

In the American double continent, the Non-Aligned Movement faced obstacles to mobilising members that were similar to those in Europe. Only one country from that region became a member at the founding conference in 1961 - Fidel Castro's Cuba, which was about to turn to the Soviet Union. Nine smaller and medium-sized states joined over the course of the 1970s and another six in the early 1980s. But none of the large countries-like Argentina, Brazil, or Mexico - joined, though some sent observers to various summits. There is a variety of reasons for this anomaly in Non-Aligned History. First, the American double continent-with exceptions mostly in the Caribbean - had undergone decolonisation long before the Cold War, which meant that few countries saw a need to join a movement that, among some of its goals, promoted formal decolonisation. Second, the Americas 
also established the world's seminal regional organisation in 1948. At its foundation, the well-funded and well-run Organisation of American States brought the 21 mostly larger of the 35 American countries together under U.S. leadership (Meek, 1975). Third, many of the smaller Central and South American countries that were not founding members in the OAS decided to join the Non-Aligned Movement before joining the OAS over the period from the late 1960s to the early 1980s. And finally, just as the NAM emerged in the 1960s, Central and South America descended into a period of USaligned right-wing military dictatorships in a number of its countries, particularly Brazil, Argentina, and Chile (Mainwaring \& Pérez-Liñán, 2014). In this context, only a reduced number of the double continent's countriesmostly from the Caribbean - joined an organisation that was founded by a Communist (Tito) and a controversial Third World leader (Nasser). Hence, the OAS and the NAM coexisted in the 1960s and 1970s in rivalry. Some of the mostly smaller countries that decided to join the NAM before the OAS, like Guyana, Jamaica, or Nicaragua, had leftist and even pro-Soviet governments anyway. As one of the most prominent American countries, Cuba was a Non-Aligned founding member in 1961 but was suspended from the OAS a year later as a result of its Cold War alignment with the Soviet Union. Starting in the mid-1960s, Fidel Castro's leftist Cuba promoted revolution in Central and South America and Africa (Connell-Smith 1979). In the 1970s, the Caribbean country was also a central actor among the NAM's anti-imperialist left that tried to seize the movement, together with Vietnam and North Korea, in an attempt to turn it into an anti-American tool. As mentioned above, Cuba prepared the Havana Summit in 1979 in close cooperation with the Soviet Union, to the chagrin of moderate NonAligned members and the condemnation of many OAS members. The Vietnamese intervention in Cambodia in late 1978 and the Soviet intervention in Afghanistan in 1979 undermined Cuba radicalism, damaged the Non-Aligned Movement, and made engagement in the OAS more attractive to many American countries than a commitment to the NAM (Lüthi, 2020, pp. 304-6, 532-35).

\section{Conclusions}

In general, the Non-Aligned Movement did not manage to establish close relations with many of the other regional organisations during the Cold War. This happened for a number of sometimes interrelated reasons. The overarching ideological superpower conflict was responsible for the creation of a number of rival organisations in various world regions 
(SEATO/ASEAN, CENTO, and OAS). Throughout the 1970s, the NAM was moving to the left, which foreclosed good relations to regional organisations that were pro-American (ASEAN and OAS). Neutralist Egypt carried the inner conflict of the Arab League into the Non-Aligned Movement. Personal rivalries or political conflict between the individual NAM leaders (Nasser and Castro) and leaders of other organisations (OAU and OAS) prevented the establishment of good relations as well. But the NAM also operated in the larger context of an increasing number of international and regional organisations, some of which were better suited or managed. Much of the NAM's agenda found a hearing anyway within the parallel United Nations system. The ASEAN formed much stronger cohesion because its smaller number of members shared a greater number of interests. As a non-regional movement, the NAM faced another two problems. First, its membership grew over time, which meant that the movement suffered from paralysis of an increasing number of opposing voices. Second, it was established on the basis of charismatic leadership by its founding fathers Tito, Nasser and Nehru, and suffered from a relatively weak institutionalisation even once it had decided to build up internal structures. In this context, the member states could choose to pursue their interests in parallel and even rival organisations. As the NAM faced internal conflict in the 1970s and the ensuing reputational damage in the early 1980s, for many members it ceased to be a prime venue of political engagement. Non-Alignment went into slow decline within a competitive global organisational environment, and eventually with the end of alliance blocks as the superpower conflict was winding down.

\section{References}

Arhiv Jugoslavije (AJ) [Archive of Yugoslavia], Belgrade.

Čavoški, J. (2017). Saving non-alignment: Diplomatic efforts of major nonaligned countries and the Sino-Indian border conflict, in: Amit Das Gupta \& L.M. Lüthi (Eds.), The Sino-Indian War of 1962: Bilateral, International, and Domestic Perspectives (pp. 160-78). Delhi, Routledge.

Connell-Smith, G. (1979). Castro's Cuba in World Affairs, 1959-79. The World Today, 35 (1), pp. 15-23.

Dinkel, J. (2015). The Movement of Non-Aligned States: Genesis, Organization, und Policies (1927-1992). Berlin, Walter de Gruyter.

Eckel, P. (1971). SEATO: An Ailing Alliance. World Affairs, 134 (2), pp. 97-114. 
Jansen, G. H. (1966). Nonalignment and the Afro-Asian states. New York, Praeger.

Jones, D., \& Smith, M. (2007). Making Process, Not Progress: ASEAN and the Evolving East Asian Regional Order. International Security, 32 (1), pp. 148-184.

Legum, C. (1975). The Organisation of African Unity-Success or Failure? International Affairs, 51 (2), pp. 208-19.

Levey, Z. (2003). The Rise and Decline of a Special Relationship: Israel and Ghana, 1957-1966. African Studies Review, 46 (1), pp. 155-177.

Lüthi, L.M. (2016). Non-Alignment, 1946-1965: Its Formation and Struggle against Afro-Asianism. Humanity, 7 (2), pp. 201-23.

Lüthi, L.M. (2020). Cold Wars: Asia, the Middle East, Europe. Cambridge, Cambridge University Press.

Mainwaring, S., \& Pérez-Liñán, A. (2014). Democracies and Dictatorships in Latin America: Emergence, Survival, and Fall. Cambridge, Cambridge University Press.

Mathews, K. (1987). Africa and Non-Alignment. India Quarterly, 43 (1), pp. 40-51.

Matthies, V. (1977). Süd/Süd-Beziehungen: Die Position Afrikas [SouthSouth Relations: The Position of Africa]. Africa Spectrum, 12 (2), pp. 185202.

Meek, G. (1975). U.S. Influence in the Organization of American States. Journal of Interamerican Studies and World Affairs, 17 (3), pp. 311-25.

National Archives of the United Kingdom (NAUK), Kew.

Politisches Archiv des Auswärtigen Amtes, Bestand: Ministerium für Auswärtige Angelegenheiten (PAAA-MfAA) [Political Archive of the Office for Foreign Affairs, Files: Ministry for Foreign Affairs], Berlin. 